\title{
Building Character Education Based on Gender Equity and Social Inclusion in Early Childhood Institution in Bandung City
}

\author{
Elly Malihah* \\ Sociology Education Department \\ Universitas Pendidikan Indonesia \\ Bandung, Indonesia \\ *ellyms@upi.edu
}

\author{
Lilis Widaningsih \\ Architecture Education Department \\ Universitas Pendidikan Indonesia \\ Bandung, Indonesia \\ liswida@upi.edu
}

\author{
Viena R Hasanah \\ Community Education Department \\ Universitas Pendidikan Indonesia \\ Bandung, Indonesia \\ viena@upi.edu
}

\begin{abstract}
The issue of gender equality and social inclusion on early childhood education is an important study. Parental care for children that does not differentiate between boys and girls, in getting access, participation and attention, is the focus of this study. The purpose of this research is to find out about several things related to: 1) Mapping of early childhood parenting in urban families; 2) Analyzing gender issues in early childhood character education in urban areas; 3) Identifying the character education curriculum based on GESI (Gender Equity and Social Inclusion) that is applied in the ECE institution in Bandung Cities. This study used a qualitative approach, using interview techniques and also distributing questionnaires to parents in 5 institutions of early childhood education. The findings indicate that parenting is dominated by authoritative parenting. Early childhood education institutions in carrying out education are proportional, with a gender equality and social inclusion perspective, providing education and care for both boys and girls.
\end{abstract}

Keywords-character education, gender equality, social inclusion

\section{INTRODUCTION}

Children are the hope for the future of the nation, based on the 2010 population census issued by the Central Statistics Agency (BPS) [1], the total population of Indonesia in 2017 is 264 million, around 4,605,808 people are early childhood (AUD) or aged less than 4 years old. less than 5 years. The distribution according to gender in this AUD group was $93.32 \%$ women and $92.96 \%$ men. With a population of about a quarter of a billion, Indonesia is faced with various problems, including the fields of population, economy, health and education. Care and education for early childhood are important pillars for further development, be it physical, cognitive, emotional, language, artistic and spiritual development [2]. Optimal development will result in human resources with character and quality.

The family is the first and foremost place for the growth and development of a child, so that the role and function of the family is very important and responsible for the child's development [3]. Human character education needs to be done from an early age, where according to Thomas Lickona [4], character education is important from an early age. Since a child is a child, it must be accustomed to rules and good, honest and fair qualities in accordance with the child's level of development. The status and role of women in the family are as housewives and mothers for their children. In certain cases, it could be that the mother is also a source of family finances that also earns the main or additional income. This condition makes women or mothers get a double burden, while the main task of educating children can be neglected [5].

Issues of justice and gender equality and social inclusion need attention [6]. According to the International Development Partners Group, Nepal, 2017, inclusive groups can consist of women, children and the elderly, disabled communities, disaster victims, and others [7-10].

This research is to find out several things related to: 1) Mapping of early childhood parenting in urban families; 2) Analyzing gender issues in early childhood character education in urban areas; 3) Identifying a character education curriculum based on gender equality and inclusion that is implemented in early childhood education institutions in Bandung City. The 
research location will be focused on five early childhood education institutions.

\section{METHODS}

The research approach is qualitative supported by quantitative data. The research method used was participatory observation, in-depth interviews, FGD, a survey of AUD parents and documentation. This research in the city of Bandung took respondents, both early childhood, parents, teachers and managers of five PAUD institutions in the city of Bandung.

The characteristics of the five institutions are that they are the best PAUD institutions in Bandung, which are among the best PAUD in 30 sub-districts in Bandung City. In this case, the five PAUD institutions already have a vision and mission to build early childhood character with a holistic and integrated approach, because it is already a PAUD institution that runs the Holistic Integrative PAUD program run by the Ministry of Education and Culture through the Directorate of Early Childhood Education.

In collecting data on early childhood parenting, questionnaires and interviews were distributed to parents in kindergarten and early childhood education both in Bandung City and in Sumedang Regency.

Respondents involved in data collection were 20 (twenty) parents, both father and mother in Bandung City and 24 (twenty-four) parents, both father and mother in Sumedang Regency. The questionnaire consisted of 62 statement items, which showed three types of parenting styles, where for Authoritative parenting, it included 27 items, Authoritarian was shown in 20 items and permissive was shown in 15 items, which were not consecutive.

Authoritative parenting patterns, shown in the statement in the questionnaire, namely: encouraging children to talk about the problem, knowing the names of their children's friends, giving praise if the child behaves well, joking and playing with children, showing sympathy when the child is injured or stressed (frustrated), calming children when the child is upset, being relaxed / relaxed with the child, explaining to the child about our hopes before the child is involved in an activity, showing / giving patience to the child, being responsible for the child's feelings and needs, allowing / giving freedom to the child to provide input regarding rules in the family, giving reasons why rules must be obeyed, appreciating what children have tried or accomplished, encouraging children to speak and understand the impact and consequences of their behavior, considering children's wishes before asking children to do something, understanding children's problems at school, expressing love dear with how to hug, kiss and hold the child, apologize to the child when making a mistake in parenting, discuss with the child when the child is behaving inappropriately, have a warm and intimate time with the child, encourage children to be free to express themselves even when they disagree with their parents, respecting children's opinions by encouraging them to express them, explaining to children how parents feel if children behave well, considering children's preferences in making family plans, explaining the consequences of children's behavior, channeling children's bad behavior into more acceptable activities, and emphasizing reasons in applying the rules.

Authoritarian parenting patterns, shown in the statement in the questionnaire, namely: giving more punishment than listening to the reasons, hitting when the child does not comply, punishing by taking (special) rights of the child without or with little explanation, yelling / scolding the child loudly when the child behaves bad, scolding or criticizing the child so that the child is better, taking / pulling the child when the child is disobedient, arguing with the child, more concerned with their own feelings than the child's feelings, punishing the child by placing the child in a place alone with little explanation, exploding anger -charring at children, using physical punishment as a way of disciplining children, telling children what to do, slapping children when children disturb others, disagreeing / disagreeing with children, when children fight they discipline the children first then ask them , scolding or criticizing when the child's behavior is not $\mathrm{k}$ according to the expectations of the parents, using threats as punishment, when children ask why they have to do something, we answer "because the father/mother wants to do that" or "because the father/mother is your parent", Require the child to do something, Encourage the child when the child is disobedient

Permissive parenting patterns, shown in the statement in the questionnaire, are as follows: it is very difficult to discipline children, refrain from scolding and / or criticizing when the child behaves against our wishes, spoils the child, allows the child to disturb the child / other person, gives punishment to even though the child does not really punish him/her, is confident in the ability to take care of the child, is afraid to discipline the child because it will cause the child to dislike his parents, threatens to punish the child more than punishes him, ignores the child's bad behavior, applies discipline after the child misbehaves, gives up to children when the child causes trouble, allows the child to disturb others, gives the child gifts to show obedience, applies strict rules for the child, feels unsure about how to solve the child's mistakes.

\section{FINDINGS AND DISCUSSION}

The results of data collection through distributing questionnaires regarding the tendency of parents' attitudes in parenting, from 20 mother respondents and 20 father respondents, in Bandung City, the results showed that the tendency of mothers to practice authoritarian parenting with an average score of 3.64 for authoritative parenting, a score of 2.16 for authoritarian parenting, and a score of 2.60 for permissive parenting.

The following is a table of the results of the maternal parenting style questionnaire in Bandung, as follows table 1: 
TABLE I. RESUlTS OF PARENTING QUESTIONNAIRE SCORING IN BANDUNG CITY

\begin{tabular}{|l|l|l|}
\hline \multicolumn{1}{|c|}{ Authoritative } & Authoritarian & Permissive \\
\hline 3.14 & 2.15 & 2.13 \\
\hline 3.4 & 2.55 & 2.86 \\
\hline 3.29 & 2.35 & 2.26 \\
\hline 3.9 & 2.5 & 3.1 \\
\hline 3.4 & 2.6 & 2.8 \\
\hline 4.2 & 1.7 & 2.6 \\
\hline 4.18 & 2.05 & 2.93 \\
\hline 4.18 & 1.8 & 2.6 \\
\hline 0 & 0 & 0 \\
\hline 4.1 & 2.1 & 3.2 \\
\hline 4.4 & 1.6 & 2.1 \\
\hline 4.2 & 1.7 & 2.6 \\
\hline 4.3 & 3.1 & 2.5 \\
\hline 3.9 & 3.1 & 2.6 \\
\hline 3.8 & 2.1 & 3.1 \\
\hline 3.4 & 2.6 & 2.8 \\
\hline 3.3 & 2.8 & 2.8 \\
\hline 4.07 & 2.6 & 3.4 \\
\hline 3.92 & 2.1 & 3.26 \\
\hline 3.66 & 1.75 & 2.3 \\
\hline 3.64 & 2.16 & 2.60 \\
\hline & & \\
\hline & & \\
\hline & & \\
\hline
\end{tabular}

As in the form of a diagram, it can be seen that the distribution of parental pattern of data in Bandung is as follows figure 1:

authoritative $\mathbf{m}$ Authoritarian $\mathbf{m}$ Permissive

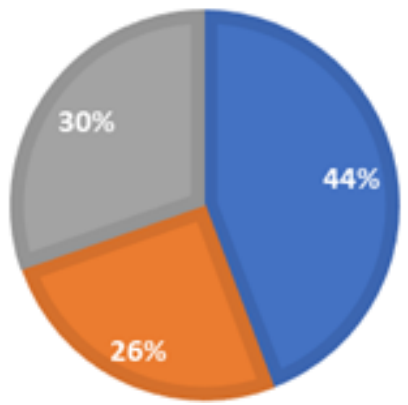

Fig. 1. Parenting patterns in Bandung City.

Based on the scoring results in the table above, which is shown in the diagram above, it can be interpreted that the parenting patterns that tend to be carried out by parents in early childhood education in the city of Bandung are authoritative, at $44 \%$, followed by permissive parenting and then authoritarian.

In knowing gender issues in early childhood character education, apart from interviews, information is also obtained through FGD (Forum Group Discussion) with teachers, parents, managers of kindergarten and early childhood education institutions and stakeholders.

\section{A. The Institutional Perspective}

If you look at the city and village / district areas, based on the results of observations and documentation studies, obtained from the SKH and the syllabus as well as the institution's vision and mission, in general kindergarten schools in the Bandung
City area have made character planting from an early age become their goal or mission and vision.

The understanding of justice and gender equality in the City of Bandung is relatively more even. In the city of Bandung in general, kindergarten which is the study, has instilled character values from an early age. Like in religious schools, TK A has the basic concept of cultivating morals with the aim of forming superior human character. Kindergarten Assalaam has 9 pillars in instilling character at an early age, such as:

- Love Allah,

- Responsible,

- Discipline,

- Independence,

- Honest,

- Compassion,

- Confident,

- Never give up, and

- Leadership.

Kindergarten A also has a curriculum that refers to the Ministerial Regulation which adopts a "Character-Based Holistic Learning" approach and the curriculum owned by TK $\mathrm{A}$ is expected to make learning more meaningful and enjoyable for children. Character education is the goal of national education and it is important to start with education at an early age [11].

The results of the discussion through FGD revealed that in Kindergarten A, justice for the treatment of boys and girls had been implemented. The access that can be obtained is not differentiated for both boys and girls. Even various activities that are considered only belong to women, such as cooking, dancing, singing, are equally given opportunities to men openly. On the other hand, access to playing in the field, selfdefense, and outdoor games is not only given to boys, but girls are also encouraged and given the same opportunities according to their interests and talents and desires with guidance from the teachers.

"Alhamdulillah, we are holding an extracurricular dance, where the teacher is a boy. Both male and female participants are allowed.

"Likewise with the" Cooking Class "activity, we routinely hold every month, there both girls and boys are involved to be actively involved in cooking snacks for school supplies" (Teacher respondent A)

Social Inclusion Services at TK A Kota Bandung have been carried out. Currently, kindergarten institutions serve children with special needs (ABK) to be able to follow the learning process with other children. The teacher stated in the clustered discussion, that:

"For inclusion, we do not declare but try to provide pedagogical inclusion services (support system) for individual learning, and helper 2 people. There are also children who are 
required to use a helper, if the child is identified it can endanger other students. For therapists, we have occupational therapists so that some of our children serve, both those with sensory problems, independence, soft skills, and speech skills.

"This year, because $60 \%$ of children have problems in concentration, we provide a special stimulation room, as a facility provided because parents object to escorting and picking up therapy children, and schools facilitate".

In addition to TK A, which instills character values at an early age, four other schools have also instilled them, this can be seen from the vision and mission of each kindergarten. Like this, the vision of Kindergarten B is the realization of a child's personality that is complete, constructive, proportional, confident, independent, ethical, healthy, and strong. Then there is also Kindergarten $\mathrm{C}$ which uses a group learning model with the aim that students can work together and have a high social sense in their environment. Likewise, with TK D and TK E. The educational model in early childhood refers to the thoughts of experts and refers to the stages of psychological development and other developments [12].

\section{B. Parents' Perspective}

Based on the results of interviews with parents regarding gender equality and social inclusion, there were those who said there was no difference in caring for or disciplining children, but there were also those who said there were differences in how to instill discipline in children, which lay in differences in children's attitudes, different levels of discipline., boys can do women's work (same but with different portions) and each child has their own dose.

In addition, parents have also familiarized children with social care, for example by introducing and explaining the importance of sharing and teaching children to share with less fortunate people, such as beggars, street singers. Early childhood development stage requires stimulation in accordance with the child's development, so that it can grow optimally [12].

\section{Perceptions of the Community's Environment}

From the general description of the community environment around the kindergarten we visited, it is very supportive of the kindergarten learning, seen from the many enthusiasts from the surrounding community, there are even some who are quite far from the kindergarten from many enthusiasts, there are several kindergartens to open two. Learning sessions from morning to noon and continued from noon to evening and the community around the kindergarten did not feel disturbed by the kindergarten

\section{Attention to the Needs of Girls and Boys}

From the school, the need that must be considered is the teacher's understanding of gender-based learning models so that there are still statements or problems such as the teacher saying "boys don't cry, strong men" apart from that there is a lack of male educators in kindergarten. what we observed was that there was only one kindergarten that had two male kindergarten teachers.

The results of the FGD showed that in TK B Bandung, the learning centers were divided into three, namely the division of centers for each child to move between classes. "Every day the children memorize which class they are in, and with whose teacher. The number of children this year is 111 students, center teacher 6 , assistant 9 people, day care there are 5 people, intra-computer teacher, dancing (there are boys) and futsal. There are swimming pool and sand pool facilities in the beam center. And it is combined between men and women, while for bathing it is separated between men and women. The swimming pool is rotated in one week per class and between men and women are combined, accompanied by the center block teacher and accompanied by several other teachers. The activities carried out between men and women are not selective, it's just that their appearance is told through parents that they must bring a change of clothes.

\section{E. Provide Space for Inclusion Groups}

Of all the institutions observed, each school has children with special needs because all these institutions have implemented inclusive education. Every school and class has a helper teacher who specifically handles children with these needs. In fact, there is one institution that does provide a special laboratory for children with needs. The function of the laboratory is to distract and calm the child, when the child is tantrums or uncomfortable.

One form of institutional attention to poor families is by holding classes in the afternoon. They can use all the facilities in the school and can pay what they can. The only difference is that the lunch facilities are non-existent. There are times when learning is done together with the group in the morning. There is no difference in treatment, there are even subsidies from students and families who are more well off financially. On the one hand, this condition can build children's character so that they can pay attention to each other and appreciate and give each other. From an early age, children are taught to have good character [11].

\section{F. Physical Facilities for the Disabled}

In some kindergartens that we visited, in general, there were no special facilities to meet the needs of children with special needs. This lack of facilities is related to attention and funding support which is generally inadequate, if only relying on compulsory school fees. In this regard, it is very important for the government to pay attention to physical facilities according to the needs and conditions of children [13].

\section{G. Treatment of Vulnerable Families, Economically, Socio- Culture and Disabilities}

The treatment from the school to the children with special needs, such as providing special care in the classroom with a helper, so children with special needs are handled by one helper, after we observed that at kindergarten schools where 
the children with special needs have an upper middle economic class. Meanwhile, the treatment of middle and lower economic children was in a kindergarten which did differentiate the behavior of economic children, such as different hours of entry and return and being given food and not giving food.

The GESI model from various kindergarten schools that we visited in general can be seen from the learning process that there are indeed some schools that are applying the Gesi learning model and there are also those who do not understand Gesi learning, this is usually a problem that exists in inclusive kindergarten schools. From the various kindergartens that we visited, school data shows that the number of boys is more than the number of girls, there are several models that are indeed applied by the school to their children, such as women becoming leaders of ranks, freeing girls with ball balls from this model. men still dominate the previous field but at least some schools have implanted a gender-based learning model.

In addition to the gender-based learning model, all the kindergartens we visited were inclusive, so some kindergartens did have children with special needs, although not many, these children with special needs were very much paid attention to at school when learning starting from these children came and were warmly welcomed by the helper and the teacher even goes home to the parents of the student.

\section{H. Gender Responsive School (SRG)}

The results of the analysis of several schools in Bandung City and Sumedang Regency can be considered based on several components as follows:

1) Child development aspects: Kindergarten is divided into the categories of public, religious, and international schools in Bandung and Sumedang, some of which have met standards in the aspects of child development in terms of cognitive, such as in one of the BPI TK which is a school that has been trusted by many people by using model learning gender such as the existence of dance extracurricular activities which are not only followed by girls but also by male anal and dance coaches are also men apart from that not only men who are made as leaders when children line up for moving home but women are also often appointed and selected by the teacher to become the leader of the ranks. In addition to TK B, there is also TK C, which implements a gender model, for example, there is one woman who is indeed a soccer ball who often plays with her male friends and the school does not prohibit it, instead it supports the girl.

2) Social: From the social aspect, there are several schools that do support activities such as supporting female friends who participate in playing football and there are no negative things such as disputes or others but on the other hand there are indeed some schools that do not instill this gender model, including there are teachers who differentiate men are stronger than women.
3) Physical environment: The environment of some of the schools that we visited has different physical environments but in general, the physical environment is the playground of each school, the games are not special games for boys and girls but can be used by both men and women. women and indeed the physical environment of each institution has a different land area for a very large area the school has a swimming pool, a sand pool until the facilities and infrastructure are very adequate, in contrast to the tk which is indeed a small land area only has friends to play and even then it is limited and only has one class and in the classroom it is shared with the teacher's room, the principal's room and the guest waiting room. The physical environment is the main support in creating a gender-friendly school situation [14].

\section{CONCLUSION}

The results of the mapping of parenting styles for early childhood by families / parents show that authoritative parenting has dominated parenting styles by families. On the institutional side, TK and PAUD in Bandung City relatively have a vision and mission in building character and gender perspective and social inclusion, which is shown by the learning process and existing facilities in the institution, although it does not explicitly mention it in the written curriculum.

\section{ACKNOWLEDGMENT}

This article is part of a research collaboration between universities in the KRUPT Research scheme (Consortium for Higher Education Excellence Research). Thanks to the Ministry of Research and Technology, which funded this research.

\section{REFERENCES}

[1] Badan Pusat Statistik, "Statistik Indonesia 2017 [Indonesian Statistics 2017]," Jakarta BPS, 2017.

[2] J.W. Santrock, Child Development, 12 th ed. NewYork: McGraw-Hil, 2009.

[3] N.W. Suarmini, "Keluarga sebagai wahanan pertama dan utama pendidikan karakter anak," J. Sos. Hum., vol. 7, no. 1, pp. 118-135, 2014.

[4] R. Megawangi, "Pendidikan karakter untuk membangun masyarakat madani,” IPPK Indones. Herit. Found., 2003.

[5] K. Sukesi, "Peran Perempuan Dalam Pembentukan Karakter Bangsa," Semin. Nas. Peran Peremp. Dalam Pembentukan Karakter Bangsa, 2012.

[6] Asian Development Bank, Gender Equality and Social Inclusion (GESI) Action Plan.

[7] G. Equality, "Social Inclusion Working Group (GESI), International Development Partners Group, Nepal.(2017)," A common Framew. Gend. Equal. Soc. Incl.

[8] Government of Nepal, Gender Wquality and Social Inclusion (GESI) Operational Guidelines. Government of Nepal, Ministry of Urban Development. Singh Durbar, Kathmandu, 2013.

[9] Government of Nepal, Gender Equality and Social Inclusion Toolbox : Promotion for Renewable Energy Technologies. Government of Nepal, Ministry of Science, Technology and Environment, 2014 
[10] KOMPAK, Gender Equality and Social Inclusion Strategy. Kompak 2017 - 2018, 2017.

[11] S. Adisusilo, "Pembelajaran Nilai-Karakter: Konstruktivisme dan VCT sebagai Inovasi Pendekatan Pembelajaran Afektif," Jakarta PT Raja Graf. Persada, 2012.

[12] A. Yus, Model pendidikan anak usia dini. Kencana, 2011.
[13] SNV, Sustainable Sanitation and Hygiene for All : Gender Equality and Social Inclusion Learning Brief. 2013.

[14] K. Kristanto, I. Khasanah, and M. Karmila, "Identifikasi model sekolah ramah anak (sra) jenjang satuan pendidikan anak usia dini se-kecamatan Semarang selatan," Paudia J. Penelit. Dalam Bid. Pendidik. Anak Usia Dini, vol. 1, no. 1, 2011. 